\title{
Biotype and molecular fingerprints of metronidazole- resistant strains of Helicobacter pylori from antral gastric mucosa
}

\author{
R. J. OWEN, G. D. BELL*, M. DESAI, M. MORENO, P. W. GANT†, P. H. JONES $†$ and D. LINTON
}

National Collection of Type Cultures, Central Public Health Laboratory, 61 Colindale Avenue, London NW9 5 HT. and ${ }^{*}$ Department of Medicine and + Public Health Laboratory, The Ipswich Hospital, Heath Road Wing, Ipswich IP4 5PD

\begin{abstract}
Summary. Biotypes, ribosomal RNA gene restriction patterns (ribopatterns), whole-cell protein patterns and plasmid profiles of paired Helicobacter pylori isolates from 17 patients were examined. Each pair comprised a pre- and a post-treatment isolate; nine of the 17 posttreatment isolates were obtained after treatment with tripotassium dicitrate bismuthate (DeNol) and metronidazole. All strains of $H$. pylori had identical biotypes, but exhibited diversity between pairs in their molecular fingerprints. Each of the 17 strain pairs had unique ribopatterns; the pre- and post-treatment isolates in most pairs (16 of 17) were similar or identical. irrespective of metronidazole susceptibility. DNA subtype variants were detected in three patient sets. Although nine post-treatment isolates had acquired resistance to metronidazole. most (six of nine) resembled the pre-treatment isolates in their ribopattern, protein and plasmid profiles. No significant correlation was observed between metronidazole resistance and plasmid content in these $H$. pylori isolates. Emergence of post-treatment metronidazole-resistant isolates of $H$. pylori was associated only rarely with colonisation by a novel strain or acquisition of a plasmid and, in most patients, probably resulted from spontaneous emergence of resistance in the original infecting strain.
\end{abstract}

\section{Introduction}

Helicobacter pylori is a gram-negative micro-aerobic bacterium, originally classified as Campylobacter, with a world-wide distribution in the gastric mucosa of man. Interest in the organism has developed over the past decade because of its association with active chronic gastritis ${ }^{2}$ and its identification as a risk factor in peptic ulcer disease ${ }^{3}$ and gastric cancer. ${ }^{4}$ Considerable research has been directed towards finding the best treatment combination to eradicate $H$. p $\mathrm{r}$ lori. A combination of tripotassium dicitrate bismuthate (De-Nol) and metronidazole was shown to be an effective treatment for $H$. pllori infection, ${ }^{6}$ and an eradication rate of c. $85 \%$ was achieved in patients whose pre-treatment isolates were sensitive to metronidazole. Further investigations of patients in whom treatment failed to eradicate $H . p y$ lori revealed that the organism had become resistant to metronidazole. Although. at the moment, some success can be achieved in treating patients whose isolates are sensitive to metronidazole, there is a pressing need to develop a safe. effective and cheap method of eradicating metronidazole-resistant organisms.

The aim of the present study was to investigate further the strains of $H$. pylori that developed resistance to metronidazole after combination treatment with De-Nol. Although only c. $20 \%$ of $H$. pylori isolates in the UK are resistant to metronidazole, the figure in certain third world countries is well over $80 \%$, probably because of the widespread use of metronidazole to treat conditions such as giardiasis and amoebiasis. This paper describes results obtained with biotyping, ribosomal (r)RNA gene restriction digest patterns (ribopatterns), plasmid profiles and one-dimensional electrophoretic protein patterns for high resolution identification of pre- and post-treatment isolates of $H$. pvlori. Molecular fingerprinting methods were selected for the present study because their accuracy and discriminatory potential have been validated in several previous studies of $H$. pylori. ${ }^{8-10}$

\section{Materials and methods}

\section{Organisms and culture conditions}

The organisms studied ( 34 isolates from 17 patients) were cultivated from pre- and post-treatment endoscopic antral biopsies. Details of the treatment regimens have been published, ${ }^{7}$ but essential information is given in table I. A reference strain (NCTC 11637), 
Table I. Helicobacter strain designations, ribotypes and plasmid contents

\begin{tabular}{|c|c|c|c|c|}
\hline \multirow{2}{*}{$\begin{array}{l}\text { Strain } \\
\text { code* }\end{array}$} & \multicolumn{3}{|c|}{$\begin{array}{l}\text { DNA } \\
\text { ribotype with }\end{array}$} & \multirow{2}{*}{$\begin{array}{l}\text { Plasmid } \\
\text { carriage }\end{array}$} \\
\hline & HaeIII & HindIII & BstEII & \\
\hline
\end{tabular}

\begin{tabular}{rrrrr} 
A. & Pre- and post-treatment isolates & \multicolumn{2}{l}{$M T$-sensitive } \\
(i) & Treatment regimen: & De-Nol & & \\
C-I & 3 & $\ldots$ & $\ldots$ & - \\
C-II & 3 & $\ldots$ & $\ldots$ & - \\
D-I & 4 & $\ldots$ & $\ldots$ & + \\
D-II & 14 & $\ldots$ & $\ldots$ & + \\
Q-I & NC & NC & 2 & - \\
Q-II & NC & NC & 2 & -
\end{tabular}

(ii) Treatment regimen: cimetidine

$\begin{array}{lllll}\text { H-I } & 8 & \ldots & \ldots & + \\ \text { H-II } & 8 & \ldots & \ldots & + \\ \text { N-I } & \text { NC } & \text { la } & \ldots & - \\ \text { N-I } & \text { NC } & \text { lb } & \ldots & -\end{array}$

(iii) Treatment regimen: ranitidine

$\mathrm{K}-\mathrm{I} \quad 11$

K-II

B. Pre-and post-treatment isolates MTZ-resistant

(i) Treatment regimen: $M T Z+D e-N o l$

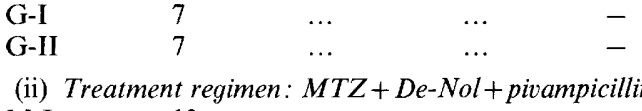

\begin{tabular}{lcccc} 
(ii) & Treatment regimen: & $M T Z+$ De-Nol & \multicolumn{2}{c}{ pivampicillin } \\
M-I & 13 & $\ldots$ & $\ldots$
\end{tabular}

M-II 13

C. Pre-treatment isolate $M T Z$-sensitive; post-treatment isolate MTZ-resistant

Treatment regimen: $M T Z+D e-N o l$

$\begin{array}{lllll}\text { A-I } & 1 & \ldots & \ldots & + \\ \text { A-II } & 1 & \ldots & \ldots & + \\ \text { B-I } & 2 & \ldots & \ldots & - \\ \text { B-II } & 2 & \ldots & \ldots & - \\ \text { E-I } & 5 & \ldots & \ldots & - \\ \text { E-II } & 5 & \ldots & \ldots & - \\ \text { F-I } & 6 a & \ldots & \ldots & - \\ \text { F-II } & 6 b & \ldots & \ldots & - \\ \text { I-I } & 9 & \ldots & \ldots & + \\ \text { I-II } & 9 & \ldots & \ldots & + \\ \text { J-I } & 10 & \ldots & \ldots & - \\ \text { J-II } & 10 & \ldots & \ldots & - \\ \text { L-I } & 12 & \ldots & \ldots & - \\ \text { L-II } & 12 & \ldots & \ldots & - \\ \text { O-I } & \text { NC } & 2 a & \ldots & (+) \\ \text { O-II } & \text { NC } & 2 b & \ldots & (+) \\ \text { P-I } & \text { NC } & \text { NC } & 2 & - \\ \text { P-II } & \text { NC } & \text { NC } & 2 & +\end{array}$

MTZ, metronidazole; NC, DNA not cut; $(+)$ indicates plasmid bands of different sizes detected in the restriction endonuclease digests only.

* Letter refers to the patient; I and II signify pre- and post-treatment isolates.

originating from Perth, Australia, was obtained from the National Collection of Type Cultures. The histological and culture methods have been described. ${ }^{11}$

All isolates of $H$. pylori were grown on Brain Heart Infusion (BHI) Agar (Oxoid) containing horse blood $5 \%$ and supplemented with Isovitalex (BBL) $1 \%$. Cultures were incubated for $48 \mathrm{~h}$ at $37^{\circ} \mathrm{C}$ under microaerobic conditions $\left(\mathrm{O}_{2} 5 \%, \mathrm{CO}_{2} 5 \%, \mathrm{H}_{2} 2 \%\right.$, $\mathrm{N}_{2} 88 \%$ ) in a Variable Atmosphere Incubator (Don Whitley Scientific Ltd, Shipley, Yorks.). Stocks of all cultures were preserved in glycerol $10 \% \mathrm{v} / \mathrm{v}$ in Nutrient Broth (Oxoid) over liquid nitrogen.
In-vitro tests for metronidazole sensitivity

In all cases, the $H$. pylori strains isolated by culture of biopsies were tested for sensitivity or resistance to metronidazole. In-vitro sensitivity tests were performed by disk diffusion with IsoSensitest Agar (Oxoid) containing lysed horse blood $5 \%$ and disks containing metronidazole $5 \mu \mathrm{g}$. Plates were incubated for $48 \mathrm{~h}$ at $37^{\circ} \mathrm{C}$ in an atmosphere of $\mathrm{O}_{2} 6 \%, \mathrm{CO}_{2}$ $10 \%, \mathrm{~N}_{2} 84 \%$. A zone of inhibition $(>10 \mathrm{~mm}$ ) was regarded as indicating susceptibility.

\section{Motility testing}

Isolates were grown on slopes of BHI blood agar with added Isovitalex as described above. The liquid phase culture at the base of the slope was removed at $24 \mathrm{~h}$, and bacterial motility was determined in hanging-drop preparations by standard methods. Strains that were weakly motile or non-motile were recultured and re-tested for motility.

\section{Enzyme biotyping}

Biotypes were determined from pre-formed enzyme production in API-Zym kits (API bioMérieux, Basingstoke, Hants.) as described. ${ }^{12}$

\section{DNA isolation, restriction digestion, vacublotting and $R N A$ gene probe hybridisation}

Chromosomal DNA was isolated and purified by the guanidium thiocyanate reagent method. ${ }^{13}$ DNA samples $(5 \mu \mathrm{g})$ were digested for $4 \mathrm{~h}$ at $37^{\circ} \mathrm{C}$ with HaeIII, HindIII, or BstEII $(2-3 \mathrm{U} / \mu \mathrm{g}$ of DNA) according to the manufacturer's instructions (Northumbria Biologicals, Cramlington, Northumbria). The digested DNA was electrophoresed at $25 \mathrm{~V}$ for $16 \mathrm{~h}$ in a horizontal agarose $0.7 \% \mathrm{w} / \mathrm{v}$ gel with buffer containing $89 \mathrm{~mm}$ Tris, $89 \mathrm{~mm}$ boric acid, $2 \mathrm{~mm}$ EDTA, $\mathrm{pH}$ 8.3. The DNA fragments were then transferred to nylon membranes (Hybond-N; Amersham International) by vacuum transfer blotting, and hybridised by standard procedures for $18 \mathrm{~h}$ at $42^{\circ} \mathrm{C}^{14}$ with a biotinylated cDNA probe. This was prepared from $16 \mathrm{~S}$ and 23S rRNA of $H$. pylori strain NCTC 11638 with Moloney mouse leukaemia virus reverse transcriptase (Gibco-BRL) ${ }^{15}$ Biotinylation was achieved by the incorporation of biotin 16-dUTP. The membranes were washed after hybridisation and the hybridised probe was detected colorimetrically with a nonradioactive detection kit (BluGENE Kit; GibcoBRL). The pattern of bands obtained was designated the ribopattern.

\section{DNA size estimation}

DNA band sizes in the blot hybridisation patterns were calculated from migration distances, either by the DNA SIZE program, based on the algorithm of Elder and Southern, ${ }^{16}$ as described previously ${ }^{17}$, or by an 


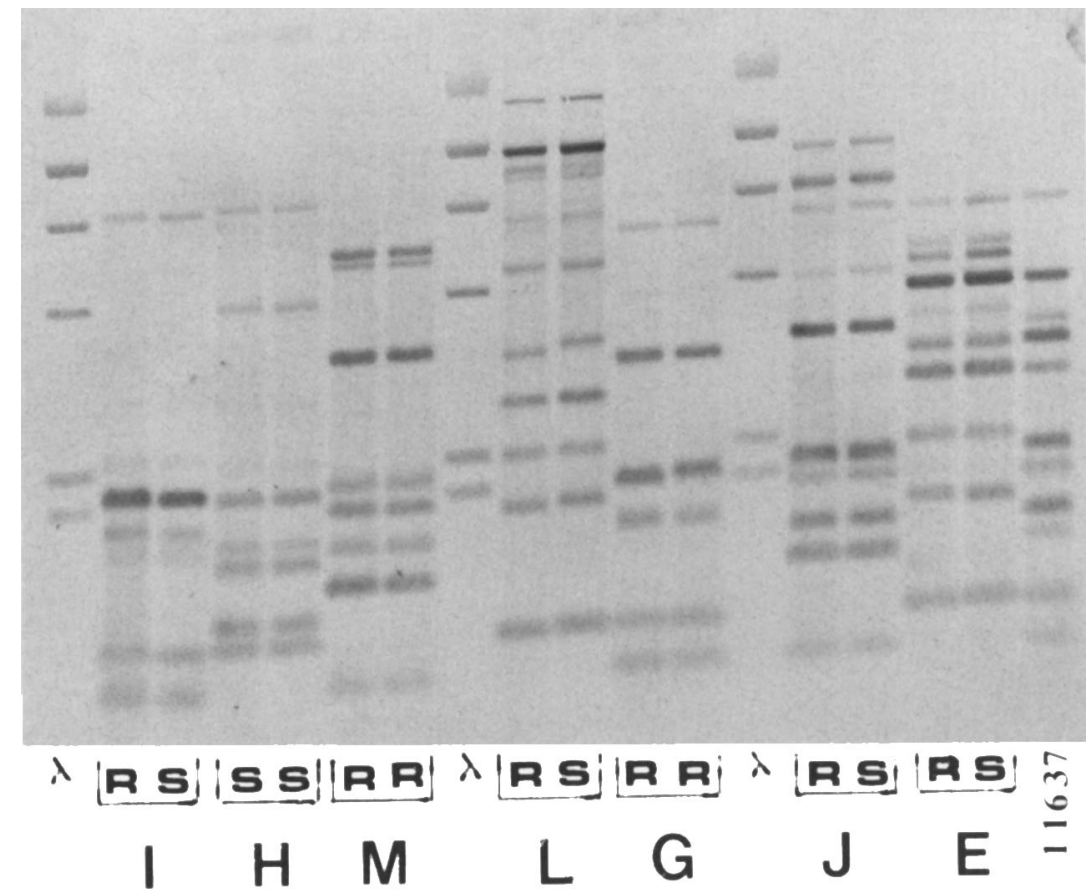

Fig. 1. Examples of the rRNA gene patterns (ribopatterns) for HaellI digests of chromosomal DNA from $H$. pylori probed with biotinylated cDNA from rRNA of strain NCTC 11638. The strain codes (table I) are indicated below the lanes. R, metronidazole-resistant; S, metronidazole-sensitive. Molecular size markers $(\mathrm{kb})$ were provided by $i$-HindIII digests.

automated gel reader and analysis system (IBI, New Haven, CT, USA). Biotinylated i phage (Gibco-BRL) digested with HindIII was used to provide the size markers. Three lanes (outside left and right, and centre) containing the markers were included on each gel.

\section{Computation of strain similarities}

To compare ribopatterns from different membranes, the bands were coded according to size to minimise errors when determining similarities by computerassisted methods of analysis. The blot hybridisation patterns were screened for bands within 21 different size ranges up to $10 \mathrm{~kb}$; positive (presence) and negative (absence) results were recorded. Bands of faint intensity were excluded. Double bands falling within a given range were scored as a single band. Computed similarities among strains were estimated by means of the Dice coefficient (negative matches excluded), and clustering of strains was based on the unweighted pair group method to facilitate the generation and plotting of a dendrogram. ${ }^{18}$ All computations were performed with the DNAGE program, a modification of described software. ${ }^{19}$

\section{Plasmid DNA extraction and electrophoresis}

For plasmid DNA extraction. organisms were cultured as described above. Single colonies were picked and plasmid DNA was prepared according to the method of Kado and Liu, ${ }^{20}$ as modified previously. ${ }^{21}$ Samples were electrophoresed in a horizontal agarose $0.7 \%$ gel for $2 \mathrm{~h}$ at $100 \mathrm{~V}$. After staining with ethidium bromide, the gels were viewed on a UVtransilluminator and photographed.

\section{PAGE of proteins}

The preparation of whole-cell protein extracts and one-dimensional (1-D) electrophoresis by discontinuous $10 \%$ SDS-PAGE was performed as described..$^{22}$ The resulting patterns were compared visually.

\section{Results}

\section{Biotype characteristics}

All the strains of $H$. pylori were motile in broth cultures and belonged to API-ZYM biotype II (producing leucine arylamidase and phosphohydrolase, but not esterases). Strains differed in their susceptibility to metronidazole, and are listed in table I according to the susceptibilities of the pre- and posttreatment isolates in each pair. Six paired isolates (12 cultures) were sensitive to metronidazole before and after treatment (set A), and two paired isolates (four cultures) were resistant to metronidazole before and after treatment (set B). The majority of the isolates (nine paired sets, 18 cultures) were sensitive to metronidazole before treatment, but were resistant to metronidazole after treatment (set $\mathrm{C}$ ).

\section{$r R N A$ gene restriction patterns}

Chromosomal DNA from each of the 34 strains of H. pylori was treated with HaeIII. DNA from eight 


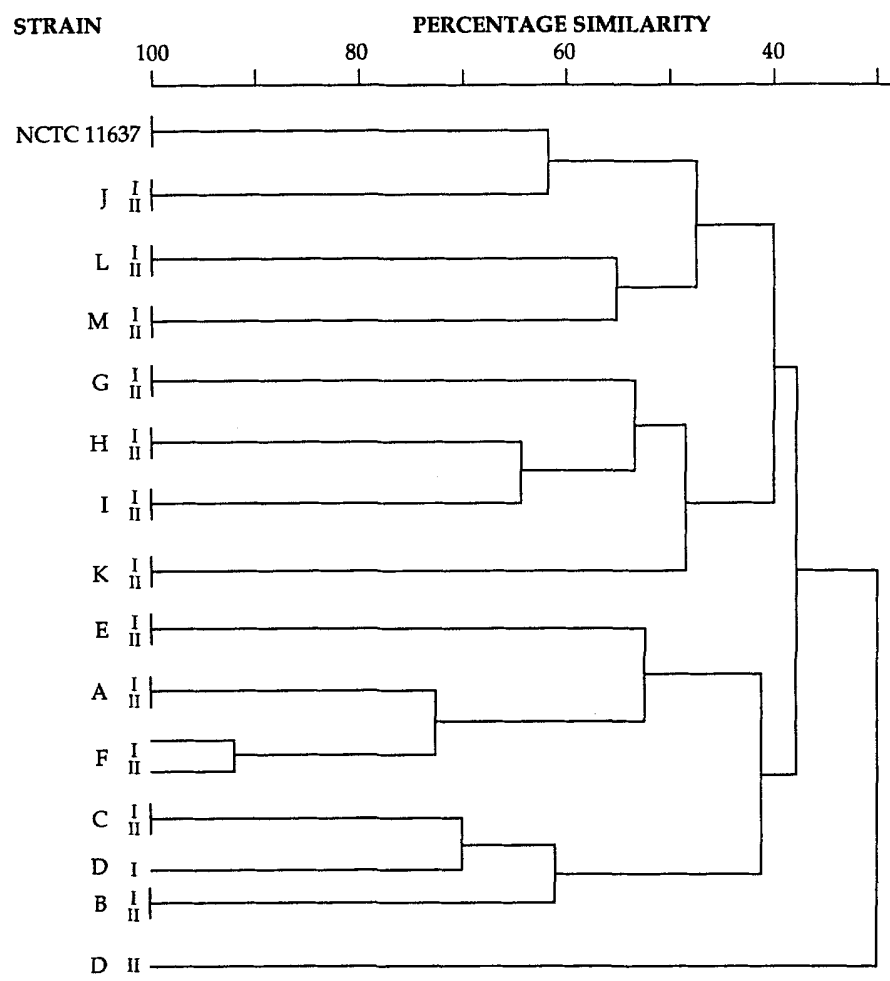

Fig. 2. Similarities between metronidazole-sensitive and -resistant strains of $H$. pylori, based on the HaeIII ribopatterns. The numbers on the horizontal axis indicate the percentage similarities as determined by the Dice coefficient and unweighted pair group average linkage clustering.

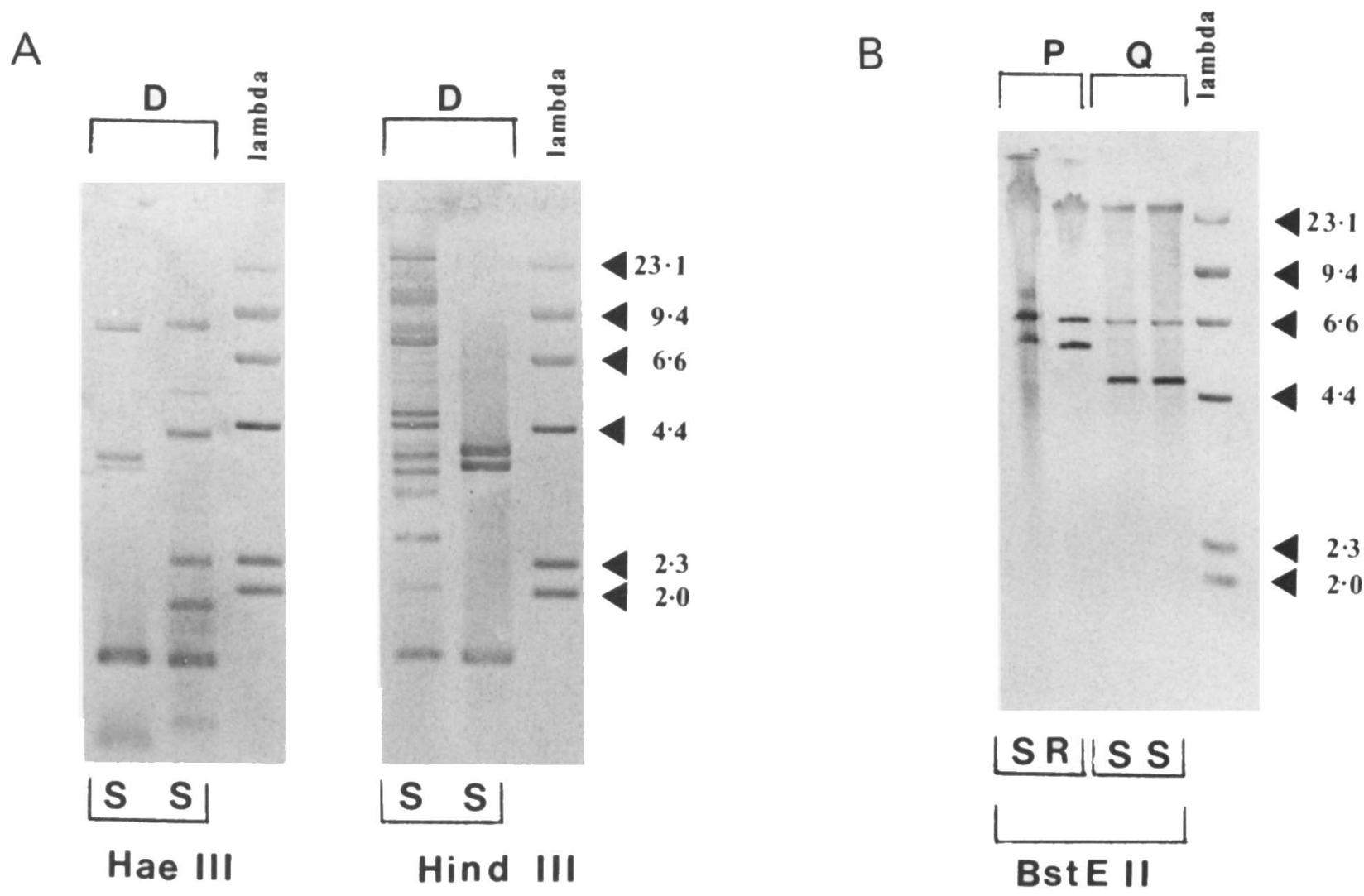

Fig. 3. The rRNA gene patterns for: (A) HaeIII and HindIII digests of chromosomal DNA from H. pylori paired isolate set D; and (B) BstEII digests of chromosomal DNA from $H$. pylori paired isolate sets $\mathrm{P}$ and Q. The strain codes are indicated by the letters above the lanes. See legend to fig. 1 for other details.

strains was not digested reproducibly by HaeIII. Examples of the HaeIII ribopatterns from the other 26 strains are illustrated in fig. 1, and the similarities between isolates derived from a numerical analysis of the results are shown in fig. 2. The analysis indicated that the pre- and post-treatment isolates in all but two (11 of 13) of the pairs had identical HaeIII ribopatterns at the $90 \%$ similarity (S) level. The differing isolates 
Table 1I. Summary of ribotyping results obtained with H. pylori paired isolates

\begin{tabular}{|c|c|c|c|}
\hline \multirow{2}{*}{$\begin{array}{l}\text { Ribopattern matches between } \\
\text { paired isolates (I and II) }\end{array}$} & \multicolumn{3}{|c|}{$\begin{array}{l}\text { Number of pairs } \\
\text { according to metronidazole } \\
\text { susceptibility }\end{array}$} \\
\hline & $R+R$ & $S+S$ & $\mathrm{~S}+\mathrm{R}$ \\
\hline Same ribotype (identical) & 2 & 4 & 7 \\
\hline Same ribotype, different subtype & 0 & 1 & 2 \\
\hline Different ribotype & 0 & 1 & 0 \\
\hline
\end{tabular}

$\mathrm{R}+\mathrm{R}$. pre- and post-treatment isolates resistant; $\mathrm{S}+\mathrm{S}$. pre- and post-treatment isolates sensitive: $S+R$, pre-treatment isolate sensitive and post-treatment isolate resistant.

were from the following two patients: Patient $D$, in whom the pre- and post-treatment isolates had completely different HaelII and HindIII ribopatterns (fig. 3A): and Patient F. in whom the pre- and posttreatment isolates had similar but not identical (two band differences) HaellI ribopatterns (results not shown), indicating that the isolates were probably genomic variants.

The eight DNA samples from the four remaining strain pairs (patients $\mathrm{N}, \mathrm{O}, \mathrm{P}$ and $\mathrm{Q}$ ) that were not cut by HaellI were examined further by digestion with either HindIII or BstEII. The resulting ribopatterns following digestion with one or other of these endonucleases showed that paired strains were identical (Bst Ell digests) from patients $\mathrm{P}$ and $\mathrm{Q}$ (fig. 3B), but were subtype variants (HindIII digests) from patients
$\mathrm{N}$ and $\mathrm{O}$ (results not shown). DNA from these strains was also treated with $B a m H I, E c o$ RI and $S a c I$, but the ribopatterns obtained were unclear and unsuitable for comparative purposes. BstEII was the only endonuclease tested that cut DNA from isolate pairs $\mathbf{P}$ and $Q$, and so their similarities had to be inferred from the two band patterns obtained. The ribotype designation ascribed to each strain is given in table $\mathrm{I}$; the results are summarised in table II according to metronidazole sensitivity.

\section{Plasmid profiles}

Plasmid DNA (single bands of $<10 \mathrm{~kb}$ ) was detected in 11 strains $(32 \%)$ by the modified method of Kado and Liu (table I), and most paired isolates had plasmids of the same size. The paired strains from patient $\mathbf{P}$ were atypical because the pre-treatment isolate was plasmid-free whereas the post-treatment isolate carried a plasmid. Although no plasmid bands were detected in paired isolates from patient $\mathrm{O}$ by the Kado and Liu method, there was evidence from total chromosomal DNA gel electrophoresis of DNA bands of differing sizes attributable to plasmids in the undigested samples (results not shown).

\section{Protein patterns}

All the strains had one-dimensional SDS-PAGE protein patterns containing the six major characteristic protein bands of $H$. pylori of $c .27,29,42,53,57$ and

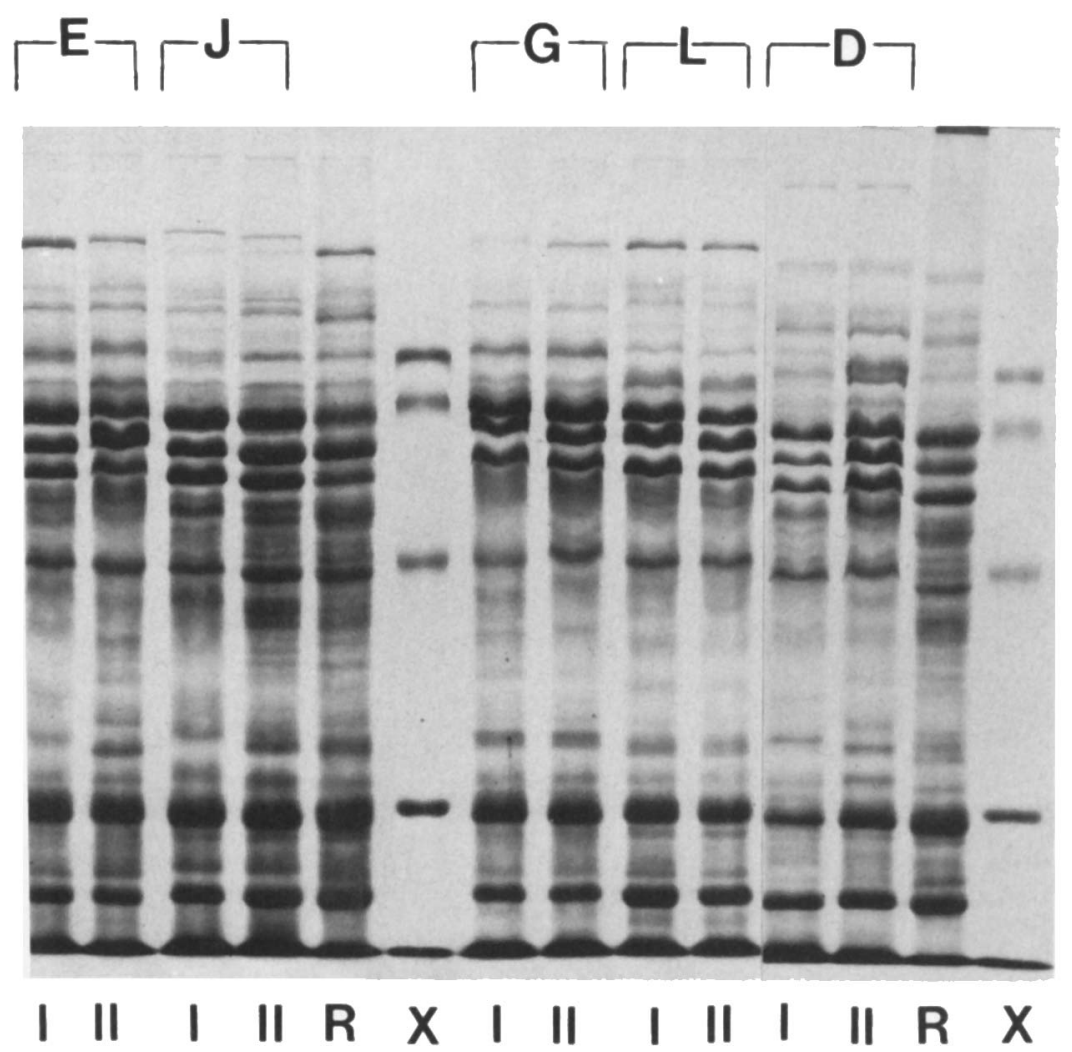

Fig. 4. Examples of electrophoretıc protein patterns of $H$. pylori isolates. The letters above the tracks refer to the patients from whom the isolates were obtained, and the Roman numerals (below) to the time of isolation (I, pre-treatment; II, post-treatment). Molecular size markers (X) are (from top to bottom): ovotransferrin, $76-78 \mathrm{kDa}$; albumin, $66.25 \mathrm{kDa}$; ovalbumin. $42.7 \mathrm{kDa}$; carbonic anhydrase, $30 \mathrm{kDa}$; myoglobin, $17.2 \mathrm{kDa}$. R, reference strain NCTC 11638. 
Table III. Comparison of $H$. pylori strains with different characteristics before and after treatment

\begin{tabular}{|c|c|c|c|c|c|}
\hline \multirow[b]{2}{*}{ Strain code } & \multicolumn{5}{|c|}{ Characteristic } \\
\hline & $\begin{array}{c}\text { MTZ } \\
\text { susceptibility }\end{array}$ & $\begin{array}{l}\text { Ribopattern } \\
\text { (enzyme) }\end{array}$ & $\begin{array}{l}\text { Plasmid } \\
\text { presence }\end{array}$ & $\begin{array}{c}\text { DNA } \\
\text { digest } \\
\text { pattern }\end{array}$ & $\begin{array}{l}\text { Protein } \\
\text { pattern }\end{array}$ \\
\hline \multicolumn{6}{|c|}{ Different ribotypes } \\
\hline D-I & $\mathrm{S}$ & 4 (HaeIII) & + & $\mathrm{U}$ & $\mathrm{U}$ \\
\hline D-II & $\mathrm{S}$ & 14 (HaeIII) & $+^{\mathrm{d}}$ & & \\
\hline \multicolumn{6}{|c|}{ Different ribo-subtypes } \\
\hline F-I & $\mathrm{S}$ & 6a (HaeIII) & - & $\mathrm{M}$ & $\mathbf{M}$ \\
\hline F-II & $\mathbf{R}$ & $6 \mathrm{~b}(\mathrm{HaeIII})$ & - & & \\
\hline N-I & $\mathrm{S}$ & 1a $($ HindIII $)$ & - & $\mathbf{M}$ & $\mathbf{M}$ \\
\hline N-II & $\mathrm{S}$ & $1 \mathrm{~b}($ HindIII $)$ & - & & \\
\hline O-I & $\mathrm{S}$ & $2 \mathrm{a}(H$ indIII $)$ & + & M & M \\
\hline O-II & $\mathrm{R}$ & $2 \mathrm{~b}($ HindIII) & $\left(++^{d}\right)$ & & \\
\hline \multicolumn{6}{|c|}{ Different plasmid content } \\
\hline P-I & $R$ & $2(B s t \mathrm{EII})$ & - & M & M \\
\hline P-II S & $\mathrm{S}$ & $2(B s t \mathrm{EII})$ & + & & \\
\hline
\end{tabular}

MTZ, metronidazole; $\mathrm{R}$, resistant; S, sensitive; +, plasmid present; -, no plasmid; M, matching patterns; $\mathrm{U}$, unmatched patterns; ${ }^{\text {d }}$, plasmids different in size; $(+)$ evidence of plasmid DNA in SacI, BamHI and EcoRI digest samples.

$64 \mathrm{kDa}$, respectively. Members of each pre- and posttreatment pair, except for those from patient $\mathrm{D}$, had identical patterns in the $47-56 \mathrm{kDa}$ hypervariable region as well as in other regions of the profile. However, there were clear protein profile differences between paired isolates from different patients (fig. 4).

\section{Summary of strain differences}

Differences in one or other of the above characteristics were detected in paired isolates from five patient sets; the results are summarised in table III.

\section{Discussion}

Previous studies have shown that $c .20 \%$ of primary H. pylori isolates are resistant to metronidazole and unlikely to respond to dual therapy with metronidazole and De-Nol. ${ }^{6,23}$ Similar frequencies of resistance have been reported in other clinical investigations, ${ }^{24-26}$ although the higher frequency of such strains in younger women was attributed to the previous use of metronidazole for gynaecological complaints. ${ }^{23,26}$ In a study of patients with primary metronidazole-sensitive $H$. pylori isolates, patients in whom the treatment failed to eradicate the organism were colonised by resistant strains. ${ }^{7}$ The results of the present study demonstrate that the same strain of $H$. pylori was present before and after treatment in all except one of these patients, although subtype differences were detected in three sets. Ribopatterns of such $H$. pylori isolates indicated no gross genomic DNA changes resulting from treatment with metronidazole, and the results were consistent with the biotype and the total protein pattern, which is a sensitive measure of expressed genomic variation.
Previous studies have demonstrated marked heterogeneity in ribopatterns amongst $H$. pylori isolates from different individuals, and have shown that strains with matching genotypes were almost exclusively from the same individual. ${ }^{8-10}$ These observations were confirmed by the results of the present study. Additional molecular features of the isolates, namely that $25 \%$ (eight of 34 isolates) had DNA that was not digested by $\mathrm{Hae}$ III, that only $30 \%$ (12 of 34 isolates) carried plasmids, and that some strains were subtype variants, were consistent with $H$. pylori results from other geographical locations in the UK, Italy, Canada, USA and South Africa. ${ }^{9,10,27,28}$

In five $(29 \%)$ of the strain pairs, some differences were observed between pre- and post-treatment isolates (table III). The isolates D-I and D-II were distinct in all characteristics, and were clearly different strains. Differences between the other paired isolates were less marked. Nevertheless, pre- and post-treatment isolates of patient pairs $\mathrm{F}, \mathrm{N}$ and $\mathrm{O}$ were clearly different subtypes, although no differences were evident in other characteristics. Similar subtype variation has been observed in sequential or multiple isolates from other patients, ${ }^{8,9,22}$ indicating that some individuals may be colonised simultaneously by a mixture of several strain subtypes, irrespective of treatment regimens.

The mode of action of metronidazole is through its conversion, under conditions of reduced oxygen tension, to a cytotoxic intermediate compound able to react with DNA and cause strand breakage. ${ }^{29}$ The cellular mechanisms for resistance to metronidazole in $H$. pylori are not known, but its emergence is probably attributable to either selection in vivo during therapy, or to the occurrence of spontaneous resistance which has been shown to occur at a low level in vitro. ${ }^{28,30}$ There was no evidence from our study to suggest that the emergence of resistance in vivo was linked to any common phenotypic marker based on biotype, or on 
bands in total protein profiles, or with any unique DNA bands in the ribopatterns. The metronidazolesensitive and -resistant strains had identical composite rRNA gene restriction fragment distributions. Furthermore, our results indicated (as found previously by Majewski and Goodwin ${ }^{28}$ ) that the emergence of resistance to metronidazole in $H$. pylori was unlikely to be attributable to plasmid-encoded determinants because there was no direct association between emergence of resistance and acquisition of a plasmid. Also, several metronidazole-resistant $H$. pylori isolates carried no plasmid DNA. and only in the strain pair from patient $P$ was there a link between emergence of resistance and acquisition of a plasmid (table III). There is no evidence of any other mechanism for

\section{References}

1. Parsonnet J. The epidemiology of C. pylori. In: Blaser MJ (ed) Campylobacter pylori in gastritis and peptic ulcer disease. New York, Igaku-Shoin Medical Publishers. 1989: 51-60.

2. Peterson WL. Helicobacter pylori and peptic ulcer disease. $N$ Engl $J$ Med 1991: 324: 1043-1048

3. Rauws EAJ, Tytgat GNJ. Cure of duodenal ulcer associated with eradication of Helicobacter pvlori. Lancer 1990: 1: 1233-1235.

4. Forman D, Newell DG, Fullerton F et al. Association between infection with Helicobacter pllori and risk of gastric cancer: evidence from a prospective investigation. BMJ $1991 ; 302$ 1302-1305

5. MiNulty CAM. Treatment of $C$. pylori infection: microbiological viewpoint. In: Blaser MJ (ed) Campylobacter pylori in gastritis and peptic ulcer disease. New York. Igaku-Shoin Medical Publishers. 1989: 195-202.

6. Weil J, Bell GD. Powell $\mathrm{K}$ et al. Helicobacter pylori infection treated with a tripotassium dicitrato bismuthate and metronidazole combination. Aliment Pharmacol Therap $1990 ; 4: 651 \cdots 657$

7. Bell GD, Weil J, Powell K et al. Helicobacter pylori treated with combinations of tripotassium dicitrato and metronidazole: efficacy of different treatment regimens and some observations on the emergence of metronidazole resistance. Eur $J$ Gastrinterol Hepatol 1991: 3:819-822.

8. Costas M. Owen RJ, Bickley J, Morgan DR. Molecular techniques for studying the epidemiology of infection by Helicohacter pylori. Scand J Gastroenterol 1991: 26 Suppl 181: 20-32

9. Owen RJ, Bickley J, Costas M, Morgan DR. Genomic variation of Helicobacter pylori: application to identification of strains. Scand J Gastroenterol 1991: 26 Suppl 181: 43-50.

10. Owen RJ, Bickley J, Moreno M. Costas M, Morgan DR. Biotype and macromolecular profiles of cytotoxin-producing strains of Helicobacter pylori from antral gastric mucosa. FEMS Microbiol Lett 1991: 79: 199-204.

11. Trowell JE, Yoong AKH. Saul KJ et al. Simple half-gram stain for showing presence of Campylobacter pyloridis in sections. I Clin Pathol 1987; 40:702.

12. Owen RJ. Desai M. Preformed enzyme profiling of Helicobacter pylori and Helicobacter mustelae from human and animal sources. Lell Appl Microbiol 1990; 11: 103-105.

13. Pitcher DG, Saunders NA, Owen RJ. Rapid extraction of bacterial genomic DNA with guanidium thiocyanate. Lett Appl Microbiol 1989:8: 151-156.

14. Owen RJ, Costas M. Dawson C. Application of different chromosomal DNA restriction digest fingerprints to specific and subspecific identification of Campylobacter isolates. J Clin Microbiol 1989:27: 2338-2343.

15. Pitcher DG, Owen RJ, Dyal P, Beck M. Synthesis of a biotinylated DNA probe to detect ribosomal RNA cistrons in Protidencia stuartii. FEMS Microbiol Lett 1987; 48: $283-287$.

16. Elder JK. Southern EM. Measurement of DNA length by gel electrophoresis II: comparison of methods for relating metronidazole resistance in $H$. pylori, although there is some evidence in Bacteroides fragilis that genetic determinants for metronidazole resistance are plasmid-borne. ${ }^{31.32}$

In conclusion, in most of the patients studied, the emergence of post-treatment metronidazole-resistant strains of $H$. pylori probably resulted from spontaneous acquisition of resistance in the original infecting strain and not from the acquisition of a novel strain from an exogenous source.

We thank K. Powell and M. Costas for assistance. M. M. was the recipient of a Junior Training Grant (BAP-0568-UK) within the framework of the CEC Research Action Programme for Biotechnology. D. L. was supported by a grant from Procter and Gamble Company, Cincinnati, $\mathrm{OH}$, USA.

mobility to fragment length. Anal Biochem 1983; 128: $227-231$

17. Owen RJ, Beck A. Evaluation of three procedures using a laser densitometer and microcomputer for estimating molecular sizes of restriction endonuclease digest fragments and application to Campylobacter jejuni chromosomal DNA. Lett Appl Microbiol 1987; 4: 5-8.

18. Sneath PHA, Sokal RR. Numerical Taxonomy. San Francisco, W. H. Freeman Co. 1973

19. Costas M. Microcomputers in the comparative analysis of onedimensional electrophoretic patterns. In: Bryce CFA (ed) Microcomputers in biochemistry: a practical approach. Oxford, IRL Oxford University Press. In press.

20. Kado CI. Liu S-T. Rapid procedure for detection and isolation of large and small plasmids. $J$ Bacteriol 1981; 145: 1365-1373.

21. Owen RJ, Hernandez J. Occurrence of plasmids in "Campylobacter upsaliensis" (catalase negative or weak group) from geographically diverse patients with gastroenteritis or bacteraemia. Eur J Epidemiol 1990; 6: 111-117.

22. Owen RJ, Costas M, Morgan DD et al. Strain variation in Campylobacter pylori detected by numerical analysis of one-dimensional electrophoretic protein patterns. Antonie Van Leeuwenhoek 1989; 55: 253-267.

23. Weil J, Bell GD, Powell K et al. Helicobacter pylori and metronidazole resistance. Lancet 1990; 336: 1445

24. Goodwin CS, Marshall BJ, Blincow ED, Wilson DH, Black bourn S, Phillips M. Prevention of nitroimidazole resistance in Campylobacter pylori by coadministration of colloidal bismuth subcitrate: clinical and in vitro studies. $J$ Clin Pathol 1988; 41 : 207-210.

25. Glupczynski Y, Burette A, De Koster E et al. Metronidazole resistance in Helicobacter pylori. Lancet 1990; 335: 976 977.

26. Becx MC, Janssen AJ, Clasener HAL, De Koning RW Metronidazole-resistant Helicobacter pvlori. Lancet 1990 335: $539-540$

27. Prewett E, Bickley J, Owen RJ. Pounder REJ. Deoxyribonucleic acid patterns of Helicobacter pylori isolated from gastric antrum, body and duodenum. Gastroenterology 1992;102 829-833.

28. Majewski SIH, Goodwin CS. Restriction endonuclease analysis of the genome of Campylobacter pylori with a rapid extraction method: evidence for considerable genomic variation. J Infect Dis 1988; 157: 465-471.

29. Ings RMJ, McFadzean JA, Ormerod WE. The mode of action of metronidazole in Trichomonas vaginalis and other microorganisms. Biochem Pharmacol 1974; 23 : 1421-1429.

30. Haas CE Nix DE, Schentag JJ. In-vitro selection of resistant Helicobacter pylori. Antimicrob Agents Chemother 1990 34: 1637-1641.

31. Breuil J, Dublanchet A, Truffaut N, Sebald M. Transferable 5nitroimidazole resistance in the Bacteroides fragilis group Plasmid 1989; $21: 151-154$.

32. Wehnert GU, Abratt VR, Goodman HJK, Woods DR. Cloning of Bacteroides fragilis plasmid genes affecting metronidazole resistance and ultraviolet survival in Escherichia coli. Plasmid 1990; 23: 155-158. 